УДК 342.92

H. С. Федорук

\title{
ПУБЛІЧНО-ПРАВОВІ ОЗНАКИ СУЧАСНОГО АДМІНІСТРАТИВНОГО ПРАВА УКРАЇНИ 3 ПОЗИЦІЙ ЛЮДИНОЦЕНТРИЗМУ
}

Постановка проблеми. Доктрина людиноцентризму здобуває все більше визнання та поширення як світоглядно-методологічна основа сучасних вітчизняних правових досліджень. Проте публічно-правові галузі вітчизняної юриспруденції продовжують залишатися ніби «за межами» людиноцентристської парадигми, хоча науковцями неодноразово наголошувалося на необхідності саме такого напряму їх розвитку. Натепер доктрина людиноцентризму знайшла більше відображення в дослідженнях приватно-правового циклу, що є цілком природним з огляду на те, що приватне право за своєю суттю і є втіленням людиноцентризму і не може повноцінно існувати і розвиватися за межами людиноцентристського світогляду. Публічно-правові галузі юриспруденції, i, зокрема, адміністративне право, перебувають у дещо іншому становищі: у визнанні науковцями необхідності їх розвитку в межах людиноцентристської парадигми, визначення критеріїв публічності тієї чи іншої галузі фактично залишається незмінним з XIX століття і відображає етатистський підхід до розуміння права. Отже, слід проаналізувати ознаки публічності адміністративного права, якими нині оперує як сучасна вітчизняна, так світова юридична наука, на предмет відповідності їх принципам людиноцентристської доктрини права.

Аналіз останніх досліджень і публікацій. Досліджуваній у статті проблематиці, а також її окремим питанням присвячували свої праці такі науковці, як: В. Авер'янов, М. Патей-Братасюк, Р. Мельник, О. Банчук, О. Харитонова, О. Миколенко та ін.

Метою статті є аналіз публічно-правових ознак адміністративного права, якими натепер оперує сучасна вітчизняна юридична наука, на предмет відповідності їх принципам людиноцентристської доктрини права.

Виклад основного матеріалу дослідження. До початку нульових «управлінська» природа адміністративного права не підлягала сумніву. У зв'язку з цим вітчизняна юридична наука впевнено розвивала радянську доктрину пріоритету держави в публічно-правових відносинах загалом і адміністративно-правових відносинах зокрема. Питання необхідності зміни світоглядної основи вітчизняного адміністративного права вперше були поставлені у працях В. Авер'янова, який наголошував, що для зміни ціннісної орієнтації адміністративного права нова адміністративно-правова доктрина має грунтуватись на протилежній - «людиноцентристській» - ідеології, згідно з якою держава має, умовно кажучи, «служити» інтересам громадян (тобто діяти на «благо людини») шляхом всебічного забезпечення пріоритету її прав, свобод та законних інтересів у сфері діяльності публічної адміністрації [1, с. 14]. 3 цього часу більшістю науковців та практиків людиноцентристську доктрину адміністративного права було визнано світоглядною основою нового адміністративного права. Але чи став людиноцентризм справді новим світоглядом учених-адміністративістів? Адже часто «людиноцентристськими» про- 
голошуються етатистські та патерналістські за своєю сутністю ідеї та принципи адміністративного права, які від радянських відрізняються лише «реформованою» термінологією (наприклад, коли термін «державне управління» замінюється на «публічне адміністрування» без зміни його світоглядної наповненості). На нашу думку, остаточна «трансформація сприйняття» (якщо використовувати термінологію Т. Куна), може статися виключно після відмови від етатистського уявлення про суть публічних відносин, публічної влади та ролі суб'єктів владних повноважень у забезпеченні інтересів та прав осіб. Не останню роль у цьому процесі грає перегляд таких фундаментальних засад доктрини адміністративного права, як публічно-правові ознаки адміністративного права. Крім того, потребують конкретизації та систематизації риси власне людиноцентристської доктрини в праві i, особливо, в його публічно-правових галузях. Публічно-правові дослідження подібного напряму часто обмежуються абстрактними і дуже узагальненими визначеннями людиноцентристського підходу без детального аналізу його реального втілення у конкретних нормах і відносинах, а також у світогляді і методології науки адміністративного права.

Отже, в чому суть ідеології людиноцентризму в адміністративному праві? Сучасне адміністративне право тлумачить людиноцентризм як «публічно-сервісне» спрямування адміністративного права (термін, запропонований ще В. Авер'яновим), відповідно до якого держава має «служити» інтересам громадян, тобто діяти заради і в ім'я приватних осіб шляхом всебічного забезпечення пріоритету їхніх прав, свобод та інтересів у публічній сфері. Нормативне обгрунтування доктрини людиноцентризму традиційно пов'язується зі ст. 3 Конституції України, в якій зазначено, що людина, її життя, честь і гідність, недоторканість і безпека визнаються в Україні найвищою соціальною цінністю. Проте, як зазначалося вище, доктрина людиноцентризму в адміністративному праві сформульована досить абстрактно, що ускладнює визначення основних проблем та напрямів розвитку адміністративного права в її межах. Отже, спробуємо визначити доктрину людиноцентризму у вигляді окремих світоглядних засад, на яких мають базуватися адміністративно-правова наука і практика, і які ми нижче у більш розгорнутому вигляді співставимо з наявними публічно-правовими ознаками адміністративного права.

1. Право розуміється не як «директива» чи припис держави, а як матеріальне відображення природного права, де суб'єкт публічної влади виступає як гарант його реалізації.

2. Публічна влада не ототожнюється виключно із застосуванням примусових заходів, а є повноваженням публічного суб'єкта на здійснення певних дій чи прийняття рішень (у тому числі і примусового характеру), необхідність яких визнана більшістю учасників суспільних відносин, у яких застосовуються владні повноваження.

3. Приватні фізичні та юридичні особи є рівними учасниками правовідносин поряд із суб'єктами публічної адміністрації.

4. Інтерес держави (або іншого суб'єкта публічної влади) не є важливішим за інтерес людини, оскільки його захист у кінцевому результаті має на меті захист прав приватних осіб. 
Тепер слід проаналізувати, яким чином зазначені принципи людиноцентризму корелюються з власне ознаками публічного права.

Критерії розмежування публічного і приватного права посідають центральне місце серед загальнотеоретичних проблем юридичної науки починаючи з часів римського права. Нині у вирішенні проблеми поділу права на публічне і приватне досить плідними визнаються саме комплексні (змішані) підходи, які є домінуючими у вітчизняній літературі [3, с. 143-151; 7, с. 10]. Наприклад, для розмежування приватного і публічного права пропонується об'єднати характер правового регулювання зі специфікою взаємин сторін і пріоритетністю волі того чи іншого суб'єкта або ж комбінування суб'єктного складу і методу правового регулювання, суб'єктного складу і інтересу, так само як і об'єднання між собою інших окремих ознак [7, с. 10]. Отже, якщо узагальнити критерії належності певної галузі до публічного права, універсальними можна виділити такі: інтерес, який захищається; особливості суб'єктного складу та взаємин між ними; особливості правового регулювання (суб'єкт, метод, принципи); особливості захисту порушених прав.

Розглянемо кожний з цих критеріїв більш детально та проаналізуємо, як вони корелюються із зазначеними вище принципами людиноцентризму.

Однією із загальновизнаних публічно-правових ознак конкретної галузі є захист публічним правом публічного інтересу.

Поняття «публічний інтерес» активно вживається у вітчизняній юридичній науці, проте його зміст залишається неоднозначним та у різних наукових джерелах може суттєво відрізнятися. Наявні варіанти змісту поняття «публічний інтерес» варіюються в межах двох протилежних точок зору: публічний інтерес розуміється або безпосередньо інтересом держави чи суспільства, які завжди є пріоритетними стосовно інтересів приватної особи [5, с. 100-104]; або ж публічними визнаються такі інтереси приватних осіб, які є однаково важливими для кожного члена суспільства [4, с. 36]. Очевидно, що протиставлення державного інтересу інтересам особи чи суспільства не зовсім відповідає зазначеним вище принципам людиноцентризму. Але як тоді відрізнити приватний інтерес від публічного і що саме буде тією «публічно-правовою ознакою", яка визначатиме його суть? Яку роль відіграватиме при цьому держава?

3 цього приводу цілком можна погодитися з твердженням Р. Мельника, що публічні інтереси - це такі інтереси приватних осіб, які є однаково важливими для кожного члена суспільства [4, с. 36]. Тобто вони відображають інтереси конкретної особи і всіх інших осіб одночасно. Натомість приватний інтерес - це інтерес, який стосується виключно конкретної особи чи декількох осіб - учасників правовідносин (наприклад, укладання договору купівлі-продажу стосується виключно інтересів покупця і продавця конкретного товару чи послуги).

3 точки зору людиноцентризму держава не може мати якийсь «власний інтерес, відмінний від інтересів окремих осіб» [5, с. 104]. Крім того, з позицій людиноцентризму держава не може бути антагоністом громадянського суспільства, а навпаки, $€$ вищою формою його організації. Держава або будь-який інший суб'єкт публічної влади забезпечує реалізацію і захист прав та інтересів кожного члена суспільства через здійснення своїх функцій шляхом реалізації владних повноважень. Засто- 
сування обмежувальних чи примусових заходів при цьому не має сприйматися як обмеження приватного інтересу, оскільки кінцевою метою таких заходів є безпека і добробут кожного конкретного громадянина (наприклад, це стосується сфери організації безпеки дорожнього руху, санітарних, протипожежних чи будівельних норм, оборони і безпеки). Про таке розуміння публічного інтересу в сучасному адміністративному праві наголошував ще В. Авер'янов, зазначаючи, що «публічний інтерес слід розуміти не як щось абстрактне, а як вагомий важіль не тільки відображення, а й забезпечення реалізації сукупності індивідуальних інтересів членів громадянського суспільства. На це орієнтує і Конституція України, яка проголосила необхідність переходу від панівної у минулому ідеології домінування держави, державних інтересів над індивідуальними до ідеології служіння держави інтересам людини, гарантування, забезпечення і захисту державою основних прав та свобод людини» [2, с. 72-73]. Отже, публічними інтересами з точки зору людиноцентризму слід вважати такі інтереси осіб, які: 1) одночасно стосуються кожної особи - члена суспільства або громади; 2) забезпечуються виключно шляхом реалізації владних повноважень, в тому числі і обмежувального характеру; 3) їх захист здійснюється з метою виконання державою своїх основних функцій із забезпечення прав та інтересів кожної особи.

До важливих ознак галузі публічного права належить наявність особливого суб'єктного складу, де обов'язковим учасником відносин є суб'єкт публічної влади. Публічне право регулює відносини приватних осіб із публічними або між публічними суб'єктами, приватне - приватних осіб між собою. Не може бути публічних відносин виключно між приватними суб'єктами. Подібні твердження в цілому не суперечать доктрині людиноцентризму. Проте необхідно зауважити, що традиційно публічні відносини трактувалися виключно як відносини «між особою і державою». Доктрина людиноцентризму не обмежує коло суб'єктів публічної влади державними органами і посадовими особами, а включає до їх складу органи місцевого самоврядування, комунальні підприємства та суб'єктів делегованих повноважень (юридичних осіб приватного права чи фізичних осіб), які на разовій або постійній основі виконують публічні функції [4, с. 18].

Однією з важливих публічно-правових ознак певної галузі вважаються особливосmі норлативного регулювання, а саме: публічне право часто забезпечує одностороннє волевиявлення суб’єктів права (імперативний метод); припускає широку сферу розсуду; може містити загальні й безособові норми, що мають нормативно-орієнтувальний вплив; характеризується переваженням директивно-обов'язкових норм, розрахованих на ієрархічні відносини суб'єктів і субординацію правових норм і актів.

3 точки зору доктрини людиноцентризму найбільше питань викликають твердження про нерівність суб'єктів публічно-правових відносин [9, с. 43], домінування в них відносин влади-підпорядкування [10, с. 760] та загальну тенденцію норм публічного права до нерівноправ'я та примусу [8]. Як уже зазначалось вище, одним із базових принципів доктрини людиноцентризму є визнання приватних фізичних i юридичних осіб рівними учасниками правовідносин поряд із суб'єктами публічної адміністрації. Відносини влади-підпорядкування в адміністративному праві мають місце лише у сфері публічної служби чи регулювання внутрішньоорганізаційної діяльності системи органів влади, коли підлеглий статус суб’єкта визначається 
його місцем у службовій ієрархії чи в системі органів влади. В усіх інших випадках приватні особи як учасники адміністративних відносин підкоряються не суб'єкту влади, а закону, так само як і ті суб'єкти владних повноважень, які вступають разом з ними у правовідносини. Можливий факт застосування примусу в таких відносинах не є свідченням підлеглого статусу суб'єкта, до якого він застосовується. Наприклад, у відносинах між патрульним поліцейським і водієм або між підприємцем і контролюючим органом всі зазначені суб'єкти діють у межах закону, яким одного суб'єкта у визначених правовою нормою ситуаціях уповноважено виносити владні приписи та застосовувати заходи примусового характеру, а другого - виконувати їх. Якщо суб'єкт владних повноважень при цьому буде діяти методом або у спосіб, що не визначений нормою права - його дії будуть визнані незаконними, а він сам стає суб'єктом юридичної відповідальності. Розуміння суб'єкта влади як основного джерела права, який на власний розсуд може наділяти чи позбавляти прав приватних осіб, є фундаментальною світоглядною помилкою багатьох вітчизняних юристів. 3 позицій вітчизняної теорії права «загальнообов' язковість «системи правил поведінки» зумовлена зовсім не загальнозначимістю права як форми втілення та вираження рівної міри справедливості та свободи, а тільки тим, що вони є велінням, наказом, волею влади. 3 огляду на це право постає засобом примусу, насильства державної влади над людиною, інструментом, який забезпечує усталеність політично-державного панування певних політичних сил, отже, про правовідносини як форму втілення формальної рівності однойменних суб'єктів права в такому разі говорити немає підстав, бо це будуть відносини домінування-підлеглості, а не рівні, партнерські, якими є правовідносини» [6, с. 7]. Розуміння публічного права як права «нерівноправ'я і примусу» є відображенням етатистського розуміння природи публічного (зокрема, $\mathrm{i}$ адміністративного) права. Примус не може вважатися ознакою виключно публічного права, адже він $є$ невід’ємною частиною і приватного права. Відмінність полягає у тому, що в приватному праві особа обмежує свою волю в інтересах однієї особи чи групи конкретних осіб (наприклад, досягаючи компромісу із контрагентами у разі укладання угоди та погоджуючись зі стягненнями у разі її порушення). Натомість у публічному праві таке обмеження відбувається в інтересах великого кола невизначених осіб у межах всієї держави чи територіальної громади (наприклад, обмеження швидкості водієм в інтересах «інших учасників дорожнього руху»). Отже, сама по собі наявність примусу та обмеження волі в інтересах інших осіб не може вважатись критерієм розмежування публічного та приватного права. Відмінність від приватного права полягає лише у колі осіб, на яких спрямовані примусові та обмежувальні заходи, а також у обов'язковій участі суб'єкта владних повноважень у разі застосування публічно-правових заходів примусу (що і зумовлено порушенням прав великого кола осіб у здійсненні протиправних дій).

Також викликає сумнів поширене твердження про те, що основним методом правового регулювання галузі публічного права $є$ імперативний метод. Стосовно особливостей адміністративно-правового регулювання ця теза вже давно піддається сумніву [2, с. 77-79]. У сучасному адміністративному праві спостерігається тенденція до посилення ролі диспозитивного методу в регулюванні адміністративних відносин. Зокрема, диспозитивність проявляється в регулюванні відносин, що 
виникають з приводу укладання адміністративних договорів, адміністративного оскарження та ін. Посилюється диспозитивний характер виконавчо-розпорядчої діяльності в таких сферах, як економіка, культура, освіта, які раніше належали винятково до сфери імперативного регулювання. У науці адміністративного права утверджується концепція про існування реординації - явища, протилежного «субординації». Вона полягає у наданні фізичним і юридичним особам, а також державним службовцям права вимагати у суб'єкта владних повноважень здійснення певних дій та створення необхідних умов для забезпечення їх належної діяльності. Такий метод характерний саме для адміністративного права і покликаний забезпечити органами виконавчої влади та місцевого самоврядування реалізацію та захист прав і свобод фізичних і юридичних осіб.

Наступною ознакою публічного права традиційно визначають певну специфіку охорони порушених прав, а саме: захист публічного права відбувається виключно за участю, а часто і за ініціативою публічного суб'єкта. Натомість втручання публічних суб’єктів для захисту приватного права відбувається у виключних випадках за умови неможливості досягнення згоди учасників таких відносин. Впровадження доктрини людиноцентризму в адміністративному праві внесло корективи і в традиційне твердження про те, що захист порушеного права відбувається виключно за ініціативи держави. Поряд із традиційним адміністративним контролем наукою адміністративного права обгрунтовується існування таких способів захисту суб'єктивних прав та інтересів, як адміністративна юстиція, звернення громадян та адміністративне оскарження [4, с. 347]. Саме такі способи охорони порушених прав базуються на визнанні рівності особи і суб'єкта владних повноважень в адміністративних відносинах і являють приклад практичної реалізації людиноцентристської «публічно-сервісної» доктрини адміністративного права, оскільки за їх допомогою приватні особи можуть захистити себе від неправомірних дій та рішень органів публічної влади.

Висновки. Аналіз загальновизнаних натепер ознак, за якими характеризується публічна галузь права, показав, що вони не повною мірою відповідають доктрині людиноцентризму, яка проголошена світоглядною основою сучасного адміністративного права України. Зокрема, суто етатистський та патерналістський зміст має поняття публічного інтересу як інтересу держави, який є вищим за інтерес особи, похідні від нього тези про нерівноправність відносин особи і держави та їх переважно примусовий характер. 3 точки зору людиноцентризму публічними інтересами слід вважати такі інтереси осіб, які одночасно стосуються кожної особи - члена суспільства або громади, захист яких здійснюється суб'єктом владних повноважень 3 метою виконання ним своїх основних функцій із забезпечення прав та інтересів кожної особи. Приватні особи є рівними учасниками адміністративних правовідносин поряд із суб'єктами публічної адміністрації (крім службових чи внутрішньоорганізаційних відносин), і в процесі реалізації своїх суб'єктивних адміністративних прав та обов'язків підкоряються не суб'єкту влади, а закону. Проявом людиноцентристського світогляду в адміністративному праві також є тенденція до збільшення ролі в реординації як методу адміністративно-правового регулювання та пов'язаних з його застосуванням адміністративно-правових способів захисту суб'єктивних прав осіб: адміністративного оскарження та звернень громадян. 


\section{Jimepamypa}

1. Авер'янов В.Б. Нова доктрина українського адміністративного права на етапі становлення. Актуальні проблеми держави і права. 2007. С. 10-16.

2. Адміністративне право України. Академічний курс в 2-х томах. Т.1. Загальна частина. Київ : Юридична думка, 2004. 584 с.

3. Банчук О. Підстави розмежування публічного і приватного права в Україні. Публічне право. 2011. № 2. C. 143-151.

4. Мельник Р.С. Загальне адміністративне право : навчальний посібник / Р.С. Мельник, В.М. Бевзенко. За заг. ред. Р.С. Мельника. Київ : Ваіте, 2014. 376с.

5. Миколенко О.І. Публічний і приватний інтерес в адміністративному праві. Правова держава. 24'2016. С. 100-104.

6. Патей-Братасюк М. Антропоцентрична теорія права : навчальний посібник. Київ. 2010. 396 с.

7. Погребняк С.П. Поділ права на публічне і приватне (загальнотеоретичні аспекти). Державне будівниитво та місиеве самоврядування. Вип. 12.2006 р. С. 3-17.

8. Сандевуар П. Введение в право / Пер. с франц. Москва : Интратэк-Р. 1994. 324 с.

9. Харитонова О. Поняття і ознаки публічних правовідносин. Вісник Академії правових наук України. № 1(28), 2002. С. 36-46.

10. Шаптала Н.К. Принципи розмежування приватного та публічного права у регулюванні фінансових відносин. Форум права. 2012. № 2. С. 759-762.

\section{Анотація}

Федорук Н. С. Публічно-правові ознаки сучасного адміністративного права України з позицій людиноцентризму. - Стаття.

У статті проведено аналіз публічно-правових ознак сучасного адміністративного права з метою оцінки їх відповідності доктрині людиноцентризму, в результаті чого доведено, що вони є етатистськими та патерналістськими за своїм змістом. Зокрема, переосмислення потребують такі моменти, як зміст поняття публічного інтересу, характер відносин між приватними особами і суб’єктами владних повноважень, суть методів правового регулювання адміністративного права та ін.

Ключові слова: людиноцентризм, етатизм, публічний інтерес, публічна влада, публічні правовідносини.

\section{Аннотация}

Федорук Н. С. Публично-правовые признаки современного административного права Украины с позиций человекоцентризма. - Статья.

В статье проведен анализ публично-правовых признаков современного административного права с целью оценки их соответствия доктрине человекоцентризма. В результате исследования доказано, что подобные признаки являются этатистскими и патерналистскими по своему содержанию, чем противоречат доктрине человекоцентризма. В связи с этим существенного переосмысления требуют такие вопросы, как содержание понятия публичного интереса, характер взаимоотношений между частными лицами и субъектами властных полномочий, сущность методов правового регулирования административного права и др.

Ключевые слова: человекоцентризм, этатизм, публичный интерес, публичная власть, публичные правоотношения.

\section{Summary}

Fedoruk N. S. Public-law features of modern administrative law of Ukraine from the standpoint of human-centeredness. - Article.

The article analyzes the features of modern administrative law publicity in order to assess its compliance with the human-centric doctrine. The study of the defining characteristics of modern administrative law as a part of public law revealed that they fail to comply fully with the human-centric doctrine since they are étatist and paternalistic by their nature. In particular, such conceptual ideas about the administrative and legal reality require rethinking, as: the nature of public interests, the character of administrative lega relations with the private persons and the subjects of public administration and the essence of the methods of administrative and legal regulation.

Key words: human-centric standpoint, étatist, public interest, public authority, public relations. 